\title{
MONITORING OF CONTAMINANTS IN NESTLING Bald Eagles of Grand Teton National Park
}

\author{
$\longrightarrow$ \\ GEORGE MONTOPOLI $\downarrow$ MATHEMATICS DEPARTMENT \\ WESTERN ARIZONA COLLEGE $\downarrow$ YUMA \\ HANK HARLOW $\downarrow$ DEPARTMENT OF ZOOLOGY AND PHYSIOLOGY \\ UNIVERSITY OF WYOMING + LARAMIE \\ ANDY BYERLY $\uparrow$ ST. JOHN'S HOSPITAL $\downarrow$ JACKSON \\ SUSAN WOLFF $\downarrow$ GRAND TETON NATIONAL PARK \\ SUSAN PATLA $\downarrow$ WYOMING GAME AND FISH $\downarrow$ JACKSON
}

\begin{abstract}
$\downarrow \quad$ AbSTRACT
We report on contaminants identified in nestling bald eagles of Grant Teton National Park (GTNP) and the Snake River Unit (SRU), Wyoming, during summers of 2006 and 2007.
\end{abstract}

We focus primarily on mercury $(\mathrm{Hg})$, lead $(\mathrm{Pb})$, and selenium $(\mathrm{Se})$ because each was detected in all nestlings during both summers at moderate levels. Independent t-tests were performed both on the raw data and logtransformed data (using the natural logarithm) as a comparative analysis to investigate if contaminant loads had significantly increased from summer 2006 to summer 2007. Also, as a comparative analysis and alternative procedure, nest site was treated as the experimental unit and a repeated-measures analysis (longitudinal study) was conducted on the raw data to investigate if contaminant loads had significantly increased from summer 2006 to summer 2007.

Results of the analysis indicate that levels of Se essentially remained unchanged from summer 2006 to summer 2007 ( $\mathrm{p}=0.466$, log-transformed data). Levels of $\mathrm{Pb}$ in nestlings increased from summer 2006 to summer 2007 $(\mathrm{p}=0.000, \log$-transformed data). There was no difference in levels of $\mathrm{Hg}$ in nestlings from summer 2006 to summer 2007 ( $\mathrm{p}=0.058, \log$ transformed data). The molar ratio $(2.54 \mathrm{ppm} \mathrm{Se:}$ $1 \mathrm{ppm} \mathrm{Hg}$ ) of Se to $\mathrm{Hg}$ did not change from 2006 to 2007 ( $\mathrm{p}=0.337$, raw data), although a $45 \%$ decrease in molar ratio was observed. Analyses of contaminants (using geometric means) in the blood of nestlings (from summer 2006 to 2007) showed a $64 \%$ increase in $\mathrm{Hg}$, a five-fold increase in $\mathrm{Pb}(481 \%)$, and a $21 \%$ increase in Se. Potential localized sources of $\mathrm{Pb}$ contamination should be identified and removed from the proximity of any nest site(s) and the study area in general.

Advancing global climate change and associated desiccation and emolation of temperate and boreal forests, exacerbated by extensive clear-cutting may increase poisoning of aquatic ecosystems with high levels of contaminants, especially $\mathrm{Hg}$, in the future. A monitoring program may be indicated to identify potential long-term changes within the GYE. 


\section{INTRODUCTION}

In the late 1980 s, toxic elements and organochlorine pesticides were analyzed in blood and sera of bald eagles (Haliaeetus leucocephalus) captured along the Snake River in northwestern Wyoming (Harmata and Oakleaf 1992). From $1985-1992,35 \%(n=146)$ of bald eagles tested had detectable levels of $\mathrm{Pb}, 91.4 \%$ had detectable levels of $\mathrm{Hg}$, and $100 \%$ had detectable levels of Se. At that time, survival and productivity of eagles did not appear affected. However, contaminant induced mortality was recorded in several eagles. Despite recommendations to monitor contaminants in nestling bald eagles at 5-year intervals (Harmata 1996), no follow-up analyses were conducted until summer 2006, after several bald eagles with $\mathrm{Hg}$ levels above the toxic threshold $(\geq 0.4 \mathrm{ppm}$ wet weight, Burgess et al. 2005) were submitted to the Montana Raptor Conservation Center (MRCC), a raptor rehabilitation and education organization in Bozeman, Montana.

Since December 2005, approximately 15 bald eagles and one golden eagle (Aquila chrysaetos) were submitted for treatment to MRCC. Analysis revealed that eagles contained toxic levels of $\mathrm{Hg}$ in their blood. Six died, one was released, and the rest remain in treatment but most likely will not be releasable. Symptoms of $\mathrm{Hg}$ toxicity were expressed by at least three other eagles submitted prior to December 2005, but their blood was not analyzed specifically for this metal. We suspect that $\mathrm{Hg}$ poisoning may have emerged prior to December 2005, but was not diagnosed.

Since the summer of 2006, we have investigated contaminants in nestling, wintering and migrant bald eagles in southwestern Montana and northwestern Wyoming. Here we report on contaminants identified in nestling bald eagles of Grand Teton National Park (GTNP) and the Snake River Unit (SRU), Wyoming, during summers of 2006 and 2007.

\section{$\uparrow$ MethodS}

Sampling was conducted at nest sites in GTNP and SRU (Table 1), along both lentic (Jackson Lake and Lower Slide Lake) and lotic systems (Snake River corridor from the Jackson
Lake dam to the Elbow south of Hoback Junction).

In this study, we focused on $\mathrm{Hg}, \mathrm{Pb}$, and Se because each was detected in all nestlings during both summers at moderate levels and, due to their persistence in the environment, are of significant concern in the GYE (especially $\mathrm{Hg}$ ). In addition, we tested six other soluble trace elements - antimony (Sb), arsenic (As), cadmium $(\mathrm{Cd})$, chromium $(\mathrm{Cr})$, nickel $(\mathrm{Ni})$ and thallium (Tl) - in 2006-2007, and DDE (organochlorine metabolite of DDT) in eight nestlings in 2007. Blood samples were analyzed at Michigan State University, Veterinary Medical Center, Diagnostic Center for Population and Animal Health, Clinical Pathology Laboratory (DCPAH), A215, East Lansing, MI 48824-1314.

\begin{tabular}{|c|c|}
\hline 2006 & 2007 \\
\hline 4LazyF Ranch (2) & 4LazyF Ranch (3) \\
\hline \multirow[t]{2}{*}{ Elbow (1) } & Elbow (2) \\
\hline & Hoback Junction (1) \\
\hline Lower Slide Lake (1) & Lower Slide Lake (2) \\
\hline \multirow[t]{2}{*}{ Moose (2) } & Moose (1) \\
\hline & Oxbow Bend (1) \\
\hline \multirow[t]{2}{*}{ Refuge (2) } & Refuge (1) \\
\hline & Spaulding Bay (2) \\
\hline Triangle X Ranch (2) & Triangle X Ranch (2) \\
\hline \multicolumn{2}{|c|}{$\begin{array}{l}\text { Table 1. Bald eagle nest sites sampled in the GYE } \\
\text { 2006-2007. (UTM locations available upon reques } \\
\text { from G.J. Montopoli). Number of nestlings in each } \\
\text { nest is given in parentheses }\end{array}$} \\
\hline
\end{tabular}

Independent-sample t-tests were conducted to investigate if contaminant loads had increased from summer 2006 to summer $2007\left(\mathrm{H}_{0}\right.$ : Levels of contaminants have not changed from 2006 to 2007; $\mathrm{H}_{1}$ : Levels of contaminants have increased from 2006 to 2007). Homogeneity of variance tests were performed to adjust for degrees of freedom if violations were present. All tests were conducted at the 0.05 level of significance.

Independent t-tests were performed both on the raw data and log-transformed data (using the natural logarithm) as a comparative analysis. The log-transformation is applicable to data expressed in ppm and uses the geometric mean (rather than the arithmetic mean) in the computation of the test statistic. 
Also, as a comparative analysis and alternative procedure, nest site was treated as the experimental unit and a repeated-measures analysis (longitudinal study) was conducted on the raw data to investigate if contaminant loads had significantly increased from summer 2006 to summer 2007. If more than one nestling occurred at any given site, levels of contaminants were averaged over all nestlings at the site. Complete data for $\mathrm{Hg}, \mathrm{Pb}$, and $\mathrm{Se}$ over both summers only occurred for 6 nest sites.

\section{$\downarrow$ Results}

The main purpose of this study involves the investigation of the occurrence of $\mathrm{Hg}, \mathrm{Pb}$, and Se in nestlings within GTNP and SRU during the two summers, 2006 and 2007. Table 2 summarizes levels of these environmental contaminants by year.

\begin{tabular}{|c|c|c|c|c|c|c|}
\hline \multirow{2}{*}{ Nest Site } & \multicolumn{2}{|l|}{$\mathrm{Hg}$} & \multicolumn{2}{|l|}{$\mathrm{Pb}$} & \multicolumn{2}{|l|}{$\mathrm{Se}$} \\
\hline & 2006 & 2007 & 2006 & 2007 & 2006 & 2007 \\
\hline \multirow[t]{3}{*}{$\begin{array}{l}\text { LazyF } \\
\text { Ranch }\end{array}$} & 0.150 & 0.204 & 0.003 & 0.019 & 0.755 & 1.415 \\
\hline & 0.261 & 0.210 & 0.003 & 0.028 & 0.823 & 1.758 \\
\hline & & 0.563 & & 0.089 & & 1.285 \\
\hline \multirow[t]{2}{*}{ Elbow Nest } & 0.614 & 0.697 & 0.004 & 0.011 & 1.477 & 1.316 \\
\hline & & 0.742 & & 0.011 & & 1.599 \\
\hline $\begin{array}{l}\text { Hoback } \\
\text { Junction }\end{array}$ & & 0.358 & & 0.014 & & 1.044 \\
\hline \multirow[t]{2}{*}{$\begin{array}{ll}\text { Lower Slide } \\
\text { Lake }\end{array}$} & 0.975 & 0.539 & 0.006 & 0.011 & 1.191 & 0.980 \\
\hline & & 0.575 & & 0.012 & & 1.270 \\
\hline \multirow[t]{2}{*}{ Moose Nest } & 0.096 & 0.230 & 0.008 & 0.012 & 0.505 & 1.896 \\
\hline & 0.291 & & 0.003 & & 0.619 & \\
\hline Oxbow Bend & & 0.797 & & 0.193 & & 1.783 \\
\hline \multirow[t]{2}{*}{ Refuge Nest } & 0.115 & 0.146 & 0.006 & 0.012 & 3.498 & 2.722 \\
\hline & 0.142 & & 0.007 & & 3.648 & \\
\hline \multirow[t]{2}{*}{$\begin{array}{l}\text { Spaulding } \\
\text { Bay }\end{array}$} & & 0.360 & & 0.021 & & 0.549 \\
\hline & & 0.367 & & 0.166 & & 0.574 \\
\hline \multirow[t]{2}{*}{$\begin{array}{ll}\text { Triangle } & X \\
\text { Ranch } & \end{array}$} & 0.212 & 0.342 & 0.014 & 0.142 & 0.542 & 1.019 \\
\hline & 0.242 & 0.407 & 0.005 & 0.120 & 0.654 & 1.318 \\
\hline \begin{tabular}{|l} 
Arithmetic \\
Mean
\end{tabular} & 0.310 & 0.436 & 0.0059 & 0.0574 & 1.371 & 1.369 \\
\hline $\begin{array}{l}\text { Geometric } \\
\text { Mean }\end{array}$ & 0.237 & 0.388 & 0.0052 & 0.0304 & 1.045 & 1.256 \\
\hline
\end{tabular}

On average (using the arithmetic mean), levels of $\mathrm{Hg}$ in nestlings increased $41 \%$ from summer 2006 to summer 2007, levels of $\mathrm{Pb}$ increased nine-fold (873\%) from summer 2006 to summer 2007, and levels of Se essentially remained unchanged over the course of the two summers. Using the geometric mean, levels of $\mathrm{Hg}$ in nestlings increased $64 \%$ from summer 2006 to summer 2007, levels of $\mathrm{Pb}$ increased five-fold $(481 \%)$ from summer 2006 to summer 2007 , and levels of Se increased $21 \%$ over the course of the two summers.

Results of the independent-samples t-tests for investigating if contaminant loads had increased from summer 2006 to summer 2007 are listed in Tables 3 through 5 below.

\begin{tabular}{llccc}
\hline & \multicolumn{2}{c}{ Raw Data } & \multicolumn{2}{c}{ Log-transformed Data } \\
\hline & F & p-Value & F & $\begin{array}{c}\text { p- } \\
\text { Value }\end{array}$ \\
\hline $\mathrm{Hg}$ & 0.13 & 0.7220 & 0.728 & 0.402 \\
$\mathrm{~Pb}$ & 31.61 & 0.0000 & 13.002 & 0.001 \\
$\mathrm{Se}$ & 6.56 & 0.0170 & 4.496 & 0.045 \\
\hline
\end{tabular}

Table 3. Summary of Homogeneity of Variance tests for the three contaminants.

Because the homogeneity of variance assumption was violated (at a significance criterion of 0.05), degrees of freedom were appropriately adjusted in the 2-sample independent $\mathrm{t}$-tests summarized below.

\begin{tabular}{|l|l|l|l|l|l|l|l|}
\hline & $\begin{array}{l}\text { Mean } \\
2006\end{array}$ & $\begin{array}{l}\text { Standard } \\
\text { Deviation } \\
2006\end{array}$ & $\begin{array}{l}\text { Mean } \\
2007\end{array}$ & $\begin{array}{l}\text { Standard } \\
\text { Deviation } \\
2007\end{array}$ & $t-$ Value & $\begin{array}{l}\text { Degrees } \\
\text { of } \\
\text { Freedom }\end{array}$ & $p$-Value \\
\hline $\mathrm{Hg}$ & 0.310 & 0.2767 & 0.436 & 0.2063 & -1.306 & 23 & 0.102 \\
\hline $\mathrm{Pb}$ & 0.0059 & 0.0033 & 0.0574 & 0.0657 & -3.030 & $14^{*}$ & 0.005 \\
\hline $\mathrm{Se}$ & 1.371 & 1.4994 & 1.369 & 0.5472 & 0.007 & $12^{*}$ & 0.497 \\
\hline $\begin{array}{l}\text { Molar } \\
\text { Ratio } \\
\text { Se:Hg }\end{array}$ & 20.464 & 27.1023 & 11.346 & 11.6329 & 1.161 & $11^{*}$ & $0.337 * *$ \\
\hline
\end{tabular}

Table 4. Summary of 2-sample independent t-tests for raw data $\left(H_{l}\right.$ : Levels of contaminants have increased from 2006 to 2007).

* Degrees of freedom based on violation of homogeneity of variance test (see Table 4)

** $\mathrm{H}_{1}$ : Molar Ratio has changed from 2006 to 2007 


\begin{tabular}{|l|c|c|c|c|c|c|c|}
\hline & $\begin{array}{c}\text { Mean } \\
2006\end{array}$ & $\begin{array}{c}\text { Standard } \\
\text { Deviation } \\
2006\end{array}$ & $\begin{array}{c}\text { Mean } \\
2007\end{array}$ & $\begin{array}{c}\text { Standard } \\
\text { Deviation } \\
2007\end{array}$ & t-Value & $\begin{array}{c}\text { Degrees } \\
\text { of } \\
\text { Freedom }\end{array}$ & p-Value \\
\hline $\mathrm{Hg}$ & -1.442 & 0.7289 & -0.947 & 0.5167 & -1.992 & 23 & 0.058 \\
\hline $\mathrm{Pb}$ & -5.254 & 0.5025 & -3.494 & 1.1456 & -5.242 & $21^{*}$ & 0.000 \\
\hline $\mathrm{Se}$ & 0.044 & 0.7284 & 0.235 & 0.4240 & -0.751 & $13^{*}$ & 0.466 \\
\hline
\end{tabular}

Table 5. Summary of 2-sample independent t-tests for log-transformed data $\left(H_{1}\right.$ : Levels of contaminants have increased from 2006 to 2007).

* Degrees of freedom based on violation of homogeneity of variance test (see Table 4)

** $\mathrm{H}_{1}$ Molar Ratio has changed from 2006 to 2007.

Results of the analysis indicate that levels of Se essentially remained unchanged from summer 2006 to summer 2007 ( $p=0.466$, log-transformed data). Levels of $\mathrm{Pb}$ in nestlings increased from summer 2006 to summer 2007 ( $p=0.000, \log$-transformed data). There was no difference in levels of $\mathrm{Hg}$ in nestlings from summer 2006 to summer 2007 ( $\mathrm{p}=0.058, \log$ transformed data). The molar ratio $(2.54 \mathrm{ppm}$ Se: $1 \mathrm{ppm} \mathrm{Hg}$ ) of $\mathrm{Se}$ to $\mathrm{Hg}$ did not change from 2006 to 2007 ( $\mathrm{p}=0.337$, raw data), although a $45 \%$ decrease in molar ratio was observed.

Results of the paired-sample t-tests conducted on the raw data to investigate if contaminant loads had significantly increased from summer 2006 to summer are given in Table

\begin{tabular}{|c|c|c|}
\hline & t-Value(d.f. $=5)$ & p-Value \\
\hline $\mathrm{Hg}$ & -0.02 & 0.4933 \\
\hline $\mathrm{Pb}$ & -1.65 & 0.0794 \\
\hline $\mathrm{Se}$ & -0.90 & 0.2049 \\
\hline
\end{tabular}

6 below.

Table 6. Summary of 2-sample independent t-tests for log-transformed data $\left(H_{1}\right.$ : Levels of metals have increased from 2006 to 2007).

Levels of soluble trace elements tested in 2006 and 2007 are summarized in Table 7.

Results of the paired-sample analysesindicate no difference in contaminant loads from summer 2006 to summer 2007. Even though a p-value of 0.0794 for $\mathrm{Pb}$ is nearly significant at the 0.05 level of significance, because data are sparse (only six nest sites), strong statistical conjecture is dubious at best.

For the most part, the six soluble trace elements listed in Table 2 were not detected or detected at low levels. Information about these trace elements is given at the end of this report (see BIOLOGICAL RELEVANCE OF THE ANALYZED CONTAMINANTS). Exceptions of concern include As in two nestlings (Refuge nest 2006 and Lower Slide Lake nest 2007); Cd in 4 nestlings (Lower Slide Lake nest 2007, Spaulding Bay nest 2007, and Triangle X Ranch nest 2007 at); $\mathrm{Cr}$ in 6 nestlings (4LazyF Ranch nest 2007, Oxbow Bend nest 2007, Spalding Bay nest 2007, and Triangle X Ranch nest 2007); and $\mathrm{Ni}$ in four nestlings (4LazyF Ranch 2007, Spaulding Bay nest 2007, and Triangle X Ranch nest 2007 at). Levels of all these metals in the nestlings, though elevated above detectable thresholds, are below toxic thresholds and will not be further discussed.

\section{DISCUSSION}

Environmental contaminants in bald eagles are a persistent issue in Montana and Wyoming. Although blood from nestling eagles surveyed during the summers of 2006 and 2007 suggest the riparian ecosystem supporting these birds contains generally low levels of contaminants, several issues of concern emerged.

Analyses of contaminants (using geometric means) in the blood of nestlings (from summer 2006 to 2007) showed a $64 \%$ increase in $\mathrm{Hg}$, a five-fold increase in $\mathrm{Pb}(481 \%)$, and a $21 \%$ increase in Se levels. In a study involving ospreys, Odsjo et al. (2004) noted that a 1:1 molar ratio $(2.54 \mathrm{ppm}$ Se: $1 \mathrm{ppm} \mathrm{Hg}$ ) is considered efficacious for detoxifying $\mathrm{Hg}$. From 2006 to 2007, the molar ratio in nestlings of our study area decreased from 20:1 to 11:1. Although it is well above the 1:1 threshold, a decrease of nearly $45 \%$ is a matter of importance. Two concerns are revealed: 1) Because Se mitigates the toxic effect of $\mathrm{Hg}$, nestlings could succumb to $\mathrm{Hg}$ toxicity if $\mathrm{Hg}$ levels increased while Se levels remained unchanged (as demonstrated by a 44.5\% decrease in molar ratio of $\mathrm{Se}: \mathrm{Hg}$ from 2006 to 2007) Currently, Se appears available to nestling bald eagles in sufficient quantities to mitigate any effects of current $\mathrm{Hg}$ contamination, but if the trend continues, $\mathrm{Hg}$ toxicity could prove fatal to nestlings, and 2) All nests that we surveyed fall within a National Park or are within geographical jurisdictions that protect the environment from contaminants. An increase in the levels of these contaminants is therefore not expected. A monitoring program may be indicated to identify potential long-term changes within the GYE. 


\begin{tabular}{|c|c|c|c|c|c|c|c|c|c|c|c|c|}
\hline \multirow{3}{*}{ Nest Site } & \multicolumn{12}{|c|}{ Soluble Trace Element } \\
\hline & \multicolumn{2}{|l|}{ As } & \multicolumn{2}{|l|}{$\mathrm{Sb}$} & \multicolumn{2}{|l|}{$\mathrm{Cd}$} & \multicolumn{2}{|l|}{$\mathrm{Cr}$} & \multicolumn{2}{|l|}{$\mathrm{Ni}$} & \multicolumn{2}{|l|}{$\mathrm{Tl}$} \\
\hline & 2006 & 2007 & 2006 & 2007 & 2006 & 2007 & 2006 & 2007 & 2006 & 2007 & 2006 & 2007 \\
\hline \multirow[t]{3}{*}{ 4LazyF Ranch } & 0.007 & 0.0050 & nd* & nd* & 0.004 & 0.0005 & & 0.012 & & 0.020 & 0.002 & nd* \\
\hline & 0.007 & 0.0080 & nd* & 0.009 & 0.004 & $0.0180^{1}$ & & 0.044 & & $0.102^{1}$ & 0.002 & nd* \\
\hline & & 0.0005 & & nd* & & 0.0040 & & $0.130^{1}$ & & 0.039 & & nd* \\
\hline \multirow[t]{2}{*}{ Elbow Nest } & 0.004 & 0.0005 & nd* & nd* & 0.004 & 0.0005 & & 0.009 & & 0.006 & 0.002 & nd* \\
\hline & & 0.0005 & & nd* & & 0.0005 & & 0.011 & & nd* & & nd* \\
\hline Hoback Junction & & 0.0005 & & nd* & & 0.0005 & & 0.010 & & nd* & & nd* \\
\hline \multirow[t]{2}{*}{ Lower Slide Lake } & 0.003 & 0.0060 & nd* & nd* & 0.009 & $0.0180^{1}$ & & 0.010 & & 0.005 & 0.002 & nd* \\
\hline & & $0.0310^{1}$ & & nd* & & 0.0005 & & 0.010 & & nd* & & nd* \\
\hline \multirow[t]{2}{*}{ Moose Nest } & 0.003 & 0.0005 & nd* & nd* & 0.005 & 0.0005 & & 0.008 & & 0.014 & 0.002 & nd* \\
\hline & 0.003 & & nd* $^{*}$ & & 0.003 & & & & & & 0.002 & nd* \\
\hline Oxbow Bend & & 0.0005 & & nd* & & 0.0005 & & $0.210^{1}$ & & 0.026 & & nd* \\
\hline \multirow[t]{2}{*}{ Refuge Nest } & 0.006 & 0.0005 & nd* $^{*}$ & nd* & 0.006 & 0.0005 & & 0.008 & & 0.006 & 0.002 & nd* \\
\hline & $0.015^{1}$ & & nd* & & 0.007 & & & & & & 0.002 & nd* \\
\hline \multirow[t]{2}{*}{ Spaulding Bay } & & 0.0005 & & 0.007 & & 0.0005 & & $0.100^{1}$ & & 0.016 & & nd* \\
\hline & & 0.0005 & & nd* & & $0.0380^{1}$ & & $0.300^{1}$ & & $0.142^{1}$ & & nd* \\
\hline \multirow[t]{2}{*}{ Triangle X Ranch } & 0.005 & 0.0005 & nd* & nd* & 0.004 & $0.0310^{1}$ & & $0.220^{1}$ & & $0.095^{1}$ & 0.002 & nd* \\
\hline & 0.004 & 0.0005 & nd* & nd* & 0.004 & $0.0350^{1}$ & & $0.220^{1}$ & & $0.106^{1}$ & 0.002 & nd* \\
\hline
\end{tabular}

Table 7. Soluble trace elements (ppm wet wt.) detected in blood of nestling bald eagles by year and nest site.

${ }^{1}=$ atypically high value, relative to other values

nd*=metal tested for, but not detected.

Independent t-tests were performed on both the original data and log-transformed data (using the natural logarithm) as a comparative analysis for $\mathrm{Hg}, \mathrm{Pb}$, and $\mathrm{Se}$ (refer to Tables 5 and $6)$.

All tests show a drop in p-value for transformed data, but of noteworthy interest is $\mathrm{Hg}$ which dropped from 0.102 for raw data to 0.058 for transformed data, suggesting an increase in power (detecting significant differences when they exist). When data are expressed in ppm, the log-transformation is the correct approach, and a p-value of 0.058 suggests further investigation with larger samples before any firm conclusions are postulated.

In addition to our investigation of $\mathrm{Pb}$, $\mathrm{Hg}$, and $\mathrm{Se}$, other contaminants of concern including $\mathrm{As}, \mathrm{Cd}, \mathrm{Cr}$, and $\mathrm{Ni}$ were encountered in some nestlings at atypically high levels when compared to other nestlings in the same nest (see Table 7). This suggests that the affected nestling may have ingested the contaminant from a specific food source (for example, a contaminated prey item). Although below toxic thresholds (see BIOLOGICAL RELEVANCE OF THE ANALYZED CONTAMINANTS), we suggest continued monitoring of these contaminants in the future.

Independent samples t-tests assume independence of nestlings within and between groups over the two summers. As an alternative procedure, we treated nest site as the experimental unit and performed a repeated measures analysis to investigate if contamination was occurring within specific environments at a generalized level from summer 2006 to summer 2007. If more than one nestling inhabited a specific nest site, levels of contaminants were averaged over all nestlings at the site. This analysis was performed on the raw data (not logtransformed) because the calculations involved do not incorporate a geometric mean if the logtransform is applied to the data. Results of this analysis indicated no difference in contaminant concentration between summer 2006 and summer 2007 for the nest sites. However, with respect to $\mathrm{Pb}$, a p-value of 0.0794 was nearly significant at the 0.05 level of significance. 


\begin{tabular}{|c|c|c|c|c|c|c|c|c|c|}
\hline & \multicolumn{2}{|c|}{$\mathrm{Hg}$} & \multicolumn{2}{|c|}{$\mathrm{Pb}$} & \multicolumn{2}{|c|}{ As } & \multirow{2}{*}{$\begin{array}{l}\mathrm{Cd} \\
2007 \\
\end{array}$} & \multirow{2}{*}{$\begin{array}{c}\mathrm{Cr} \\
2007 \\
\end{array}$} & \multirow{2}{*}{$\begin{array}{c}\mathrm{Ni} \\
2007\end{array}$} \\
\hline & 2006 & 2007 & 2006 & \begin{tabular}{|c|}
200 \\
7 \\
\end{tabular} & 2006 & 2007 & & & \\
\hline \multirow[t]{3}{*}{ 4LazyF Ranch } & & 0.204 & & 0.019 & & $0.0050^{1}$ & 0.0005 & 0.012 & 0.020 \\
\hline & & $0.563^{1}$ & & $0.089^{1}$ & & $0.0080^{1}$ & $0.0180^{1}$ & 0.044 & $0.102^{1}$ \\
\hline & & 0.210 & & 0.028 & & 0.0005 & 0.0040 & $0.130^{1}$ & 0.039 \\
\hline \multirow[t]{2}{*}{ Lower Slide Lake } & & & & & & 0.0060 & $0.0180^{1}$ & & \\
\hline & & & & & & $0.0310^{1}$ & 0.0005 & & \\
\hline \multirow[t]{2}{*}{ Moose Nest } & 0.096 & & & & & & & & \\
\hline & $0.291^{1}$ & & & & & & & & \\
\hline \multirow[t]{2}{*}{ Refuge Nest } & & & & & 0.006 & & & & \\
\hline & & & & & $0.015^{1}$ & & & & \\
\hline \multirow[t]{2}{*}{ Spaulding Bay } & & & & 0.021 & & & 0.0005 & 0.10 & 0.016 \\
\hline & & & & $0.166^{1}$ & & & $0.0380^{1}$ & $0.30^{1}$ & $0.142^{1}$ \\
\hline \multirow[t]{2}{*}{ Triangle X Ranch } & & & 0.005 & & & & & & \\
\hline & & & $0.014^{1}$ & & & & & & \\
\hline
\end{tabular}

Table 8. Noteworthy differences in contaminant loads in nests containing more than one nestling.

${ }^{1}=$ atypically high value $(>2 x)$, relative to other values in the same nest.

Because only six nest sites were included in the analysis, it is questionable whether the increase in $\mathrm{Pb}$ from summer 2006 to summer 2007 is due to pure chance, or perhaps from some environmental contamination effect. Therefore, we suggest that: 1) the repeated measures analysis approach be implement when larger sample sizes are available - it is a powerful analysis technique that minimizes the effects of extraneous variables; and, 2) potential localized sources of $\mathrm{Pb}$ contamination (for example, elk harvest where lead rifle bullets are allowed, or lead shot used in fishing) be identified and removed from the proximity of any nest site(s), with continued monitoring in the future (Craighead and Bedrosian 2008).

Several nests containing more than one nestling demonstrated substantially higher levels of contaminant loads in some nestlings when compared to other nestlings in the same nest. Table 7 below summarizes these atypically higher levels defined by at least twice the level $(>2 x)$ of other nestlings in the same nest.

Assuming that the higher levels were not a result of inaccurate laboratory analyses, the discrepancies may most likely result from contaminated prey consumed by the nestling. Contamination may be generated locally (herbicides, pesticides, poison-laced bait, lead shot, mining, etc.) or on a grander scale (environmental contamination).

Natural degassing of the earth's crust is the major source of environmental $\mathrm{Hg}$ worldwide (Heinz 1996) and coal-fired utilities are the largest single unregulated anthropogenic source of $\mathrm{Hg}$ emissions in the United States (USEPA 1997). However, recent data indicate wildfires are responsible for massive aerosols of $\mathrm{Hg}$ (Friedli et al. 2003) and could release 15 times more $\mathrm{Hg}$ into the air than every U.S. coal-fired power plant combined (Friedli et al. 2001).

Biswas et al. (2003) indicated combustion of litter and green vegetation resulted in virtually complete release of $\mathrm{Hg}$ stored in fuel and forests in the Rocky Mountain region. Montana and Wyoming forests may contain large reservoirs of $\mathrm{Hg}$ deposited during the industrial age that can be released during fires. Additionally, $\mathrm{Hg}$ concentrations in fish were related to ratio of the clear-cut (forest logging) size to lake area in Canadian boreal forests (Garcia and Carignan 2005), suggesting large scale logging operations contribute to $\mathrm{Hg}$ contamination of higher trophic-level piscivorous predators (Driscoll et al. 1994), which may bioaccumulate in higher trophic-level predators. 
Geometric-mean $\mathrm{Hg}$ concentrations were higher in nestling bald eagles sampled in Wyoming than those in Montana but both were well below that considered toxic (Harmata 2006). Perhaps higher concentrations in Wyoming nestlings are a function of their proximity to Yellowstone National Park where large, extensive forest fires occur regularly and geothermal activity abounds. Less human and industrial activity occur in the Snake River watershed above nest sites of nestling eagles sampled in Wyoming, unlike areas in the Upper Missouri River watersheds above nest sites of nestling eagles sampled in Montana. High $\mathrm{Hg}$ concentrations in eagles may therefore be a result of recent, large, intense forest fires in the Canadian boreal forest. These fires release $\mathrm{Hg}$ into the atmosphere not only from trees consumed but especially peat that absorbed disproportionate amounts of atmospheric $\mathrm{Hg}$ emitted during the industrial age (Turetsky et al. 2006). Advancing global climate change and associated desiccation and emolation of temperate and boreal forests, exacerbated by extensive clear-cutting may increase poisoning of aquatic ecosystems with high levels of $\mathrm{Hg}$ in the future. Hence, we suggest continued monitoring to identify potential long-term trends within the GYE.

\section{BIOLOGICAL RELEVANCE OF THE ANALYZED CONTAMINANTS}

\section{$\mathrm{Hg}$}

$\mathrm{Hg}$, in the form of methylmercury $\left(\mathrm{CH}_{3} \mathrm{Hg}^{+}\right)$, is bioaccumulated in organisms, has no biological benefit, and is responsible for deleterious effects in birds (USEPA 1997, Boening 2000, Nacci et al. 2005). Dietary Hg affects raptorial species neurologically (Fimreite and Karstad 1971), physiologically (Boening 2000), and reproductively (Fimreite and Karstad 1971, Wiemeyer et al. 1993). Neurological effects appear to be manifested in a threshold effect resulting in overall weakness and wasting. None of the nestling eagles sampled in this study displayed symptoms of $\mathrm{Hg}$ poisoning but 7 of 13 eagles submitted for rehabilitation in Montana did. Eagles submitted for rehabilitation exhibiting symptoms had $\mathrm{Hg}$ concentrations in blood (geometric mean $=0.9 \mathrm{ppm}$ ) higher than those that did not (geometric mean $=0.31, N=$ 6). $\mathrm{Hg}$ in blood of bald eagles submitted for rehabilitation was above that considered toxic $(\geq 0.4 \mathrm{ppm}$ wet weight; Burgess et al. 2005) and suggests these eagles fed on a highly contaminated food supply (Wiemeyer 1991). However, without feather analysis for perspective, determining if contamination was acute (recent, high level) or chronic (long-term, low level) is problematic.

\section{Se}

Se is a natural component of soils, is essential to all plants and animals, and is present at high concentrations in some arid areas of the western U.S. Se is an essential micronutrient with important biological and biochemical functions in organisms because of its unique antioxidant properties and its ability to regulate thyroid gland metabolism, but at high concentrations, it can be toxic (Lemly 1993). Dissolution of Se and other potentially toxic elements from soils and their accumulation in ecosystems are accelerated by irrigation (Eisler 1985). Burning of fossil fuels is another major source of $\mathrm{Se}$ contamination of aquatic ecosystems and elevated concentrations commonly occur in water and soils of semiarid regions of the western U.S., including Montana and Wyoming (Ohlendorf 1989).

Attributing Se toxicity to eagles is tenuous. Se induced mortality has been documented in waterfowl, but the effects are primarily teratogenic or manifested in reduced natality or productivity (Eisler 1985, Ohlendorf et al. 1986, Heinz et al. 1989, Hoffman et al. 1990). Although congenital mandibular deformities have been observed in bald eagles in the Great Lakes Region, Se was an unlikely causative agent (Bowerman et al. 1994) and similar effects have not been recorded for eagles elsewhere. No nestling eagles exhibited physical symptoms of Se poisoning despite some with very high concentrations in blood $(>3 \mathrm{ppm})$ in Wyoming. However, aberrant pied plumage has been noted in nestlings in the Greater Yellowstone Ecosystem (Harmata and Montopoli 1998) where Se concentrations have been historically elevated (arithmetic mean $>1 \mathrm{ppm}$ in nestlings, $>3 \mathrm{ppm}$ in adults; Harmata and Oakleaf 1992).

\section{Hg - Se Relationship}

Se toxicity in birds is manifested mostly in embryos (Poley and Moxon 1938, Ohlendorf et al. 1986). Se may mitigate effects of $\mathrm{Hg}$, or vice versa in organisms (Rudd et al. 1980, Pelletier 1985, Eisler 1985, Chen et al. 2006). Toxicity of $\mathrm{CH}_{3} \mathrm{Hg}^{+}$to birds may be highly dependent upon the availability of dietary Se 
(Weech et al. 2003). A 1:1 molar ratio (2.54ppm Se: $1 \mathrm{ppm} \mathrm{Hg}$ ) is considered efficacious for detoxifying $\mathrm{Hg}$ (Odsjo et al. 2004) but ratios in some seabird species in the United Kingdom had ratios of 5 to 45 to one (Hutton 1981).

\section{Pb}

There are abundant studies in the literature describing the effects of $\mathrm{Pb}$ on raptors, especially eagles (e.g., Pattee et al. 1981, Pattee and Hennes 1983, Kramer and Redig 1997). However, symptoms attributable exclusively to $\mathrm{Pb}$ toxicosis were not exhibited by any eagles in this study. Origin and implications of exposure in Wyoming nestlings will be explored in-depth by cooperators at Beringia South, Inc. (B. Bedrosian, pers. comm.).

Sb

$\mathrm{Sb}$ is found at very low levels throughout the environment. The concentration of $\mathrm{Sb}$ in ambient air ranges from less than 1 nanogram per cubic meter $\left(\mathrm{ng} / \mathrm{m}^{3}\right)$ to about 170 $\mathrm{ng} / \mathrm{m}^{3}$. However, concentrations may be greater than $1,000 \mathrm{ng} / \mathrm{m}^{3}$ near factories that convert $\mathrm{Sb}$ ores into metal or make $\mathrm{Sb}$ oxide. Soil usually contains very low concentrations of Sb (less than 1 part per million [ppm]). However, higher concentrations have been detected at hazardous waste sites and at Sb-processing sites. Food contains small amounts of $\mathrm{Sb}$ : the average concentration of $\mathrm{Sb}$ in meats, vegetables, and seafood is 0.2 to 1.1 parts per billion (ppb). People who work in industries that process $\mathrm{Sb}$ ore and metal, or make $\mathrm{Sb}$ oxide, may be exposed to $\mathrm{Sb}$ by breathing dust or by skin contact. (ATSDR 1992).

Animal studies have reported effects on the respiratory and cardiovascular systems and kidney from chronic inhalation exposure. Animal studies involving oral consumption of $\mathrm{Sb}$ have reported effects on the blood, liver, central nervous system, and gastrointestinal effects (ATSDR 1992). A National Toxicology Program (NTP 1992) 14-day drinking water study of potassium antimony tartrate reported an increase in relative liver and kidney weights in the high dose group (females only). A 13-week intraperitoneal injection study, also by the NTP, reported inflammation and/or fibrosis of the liver in mice dosed with potassium Sb tartrate. EPA has not established a Reference Concentration (RFC, or non-toxic threshold) for Sb. However, EPA has established an RFC of 0.0002 milligrams per cubic meter $\left(\mathrm{mg} / \mathrm{m}^{3}\right)$ for $\mathrm{Sb}$ trioxide based on respiratory effects in rats.

As

As is a carcinogen, teratogen, and possible mutagen in mammals (ATSDR 1993). Chronic exposure can result in anemia, neuropathy, and skin lesions that can develop into skin cancer in mammals. Benthic feeders are more susceptible to As than other aquatic organisms. In birds, tolerance to As varies among species, but effects include destruction of gut blood vessels, blood cell damage, muscular incoordination, debility, slowness, jerkiness, falling, hyperactivity, fluffed feathers, drooped eyelids, immobility, seizures, and systemic, growth, behavioral, and reproductive problems (Stanley et al. 1994; Whitworth et al. 1991; Camardese et al. 1990).

Literature and electronic search revealed no instances of arsinecosis or mortality of bald eagles directly attributable to As. Levels in blood of eagles found here may be reflective of background levels, sensitivity of analysis, or both. One-hundred percent of Wyoming nestlings exhibited detectable levels of As, one 15 times the detection limit. As contamination may be inconsequential but continued monitoring is indicated.

\section{Cd}

$\mathrm{Cd}$ is highly toxic to wildlife; carcinogenic, teratogenic, and potentially mutagenic, with severe sublethal and lethal effects at low environmental concentrations (Eisler 1985a). Cd is associated with inhibited molt, depressed respiration, low enzyme levels, muscle contractions, decreased growth and reproduction. Cd bioaccumulates at all trophic levels, accumulating in the livers and kidneys of fish (Shindayigaya et al. 1994; Sadiq 1992). However, insects and birds may be especially resistant to biocidal effects of $\mathrm{Cd}$ (White and Finley 1978). In the absence of mortality, morbidity, or reduced productivity attributed to $\mathrm{Cd}$ in local populations, $\mathrm{Cd}$ residues may be inconsequential but should be monitored.

$\mathrm{Cr}$

$\mathrm{Cr}$ occurs in the environment primarily in two valence states, trivalent $\mathrm{Cr}$ (Cr III) and hexavalent $\mathrm{Cr}$ ( $\mathrm{Cr}$ VI). Exposure may occur from natural or industrial sources of $\mathrm{Cr}$. $\mathrm{Cr}$ III is much less toxic than $\mathrm{Cr}(\mathrm{VI})$. The respiratory tract is also the major target organ for $\mathrm{Cr}$ (III) 
toxicity, similar to $\mathrm{Cr}$ (VI). $\mathrm{Cr}$ (III) is an essential element in humans. The body can detoxify some amount of $\mathrm{Cr}$ (VI) to $\mathrm{Cr}$ (III).

The respiratory tract is the major target organ for Cr (VI) toxicity, for acute (short-term) and chronic (long-term) inhalation exposures. Shortness of breath, coughing, and wheezing were reported from a case of acute exposure to $\mathrm{Cr}$ (VI), while perforations and ulcerations of the septum, bronchitis, decreased pulmonary function, pneumonia, and other respiratory effects have been noted from chronic exposure. Human studies have clearly established that inhaled $\mathrm{Cr}$ (VI) is a human carcinogen, resulting in an increased risk of lung cancer (ATSDR 1998).

Animal studies have shown Cr (VI) to cause lung tumors via inhalation exposure. Animal studies have not reported reproductive or developmental effects from inhalation exposure to $\mathrm{Cr}$ (VI). Oral studies have reported severe developmental effects in mice such as gross abnormalities and reproductive effects including decreased litter size, reduced sperm count, and degeneration of the outer cellular layer of the seminiferous tubules. (ATSDR 1998, USEPA (1) 1998). A study of mice fed high levels of $\mathrm{Cr}$ (III) in their drinking water has suggested a potential for reproductive effects, although various study characteristics preclude a definitive finding. (USEPA (2) 1998).

\section{Ni}

$\mathrm{Ni}$ occurs naturally in the environment at low levels. $\mathrm{Ni}$ is an essential element in some animal species, and it has been suggested it may be essential for human nutrition. Ni dermatitis, consisting of itching of the fingers, hands, and forearms, is the most common effect in humans from chronic (long-term) skin contact with Ni. Respiratory effects have also been reported in humans from inhalation exposure to Ni. Human and animal studies have reported an increased risk of lung and nasal cancers from exposure to $\mathrm{Ni}$ refinery dusts and $\mathrm{Ni}$ subsulfide. Animal studies of soluble $\mathrm{Ni}$ compounds (i.e., $\mathrm{Ni}$ carbonyl) have reported lung tumors. Pulmonary fibrosis and renal edema were reported in humans and animals following acute (short-term) exposure to $\mathrm{Ni}$ carbonyl. EPA has classified $\mathrm{Ni}$ refinery dust and $\mathrm{Ni}$ subsulfide as Group $\mathrm{A}$, human carcinogens, and $\mathrm{Ni}$ carbonyl as a Group B2, probable human carcinogen (USEPA 1986).
$\mathrm{Ni}$ is an essential nutrient for some mammalian species, and has been suggested to be essential for human nutrition. By extrapolation from animal data, it is estimated that a $70-\mathrm{kg}$ person would have a daily requirement of $50 \mu \mathrm{g}$ per $\mathrm{kg}$ diet of $\mathrm{Ni}$. Animal studies have reported reproductive and developmental effects, such as a decreased number of live pups per litter, increased pup mortality, and reduction in fetal body weight, and effects to the dam from oral exposure to soluble salts of Ni. Sperm abnormalities and decreased sperm count have been reported in animals exposed to $\mathrm{Ni}$ nitrate orally and $\mathrm{Ni}$ oxide by inhalation, respectively (ATSDR 1997).

\section{Th}

Th is not a rare element, being 10 times more abundant than silver. It enters the environment primarily as a trace contaminant from coal combustion and smelting. Some Th compounds are removed from the atmosphere in precipitation and persist in water and soil for long periods. Th may be absorbed by plants and enters the food chain where it is bioaccumulated in fish and higher trophic level consumers (ATSDR 1995). A recent study with planktonic communities showed that $\mathrm{Tl}^{3+}$ ions, a common form of $\mathrm{Th}$ in aquatic environments, are about 34,000 times more toxic than $\mathrm{Cd}$ ions (Twining et al. 2003), suggesting toxicity to higher vertebrates at low concentrations. For example, waterfowl have died from ingesting Thcontaminated foods obtained from aquatic environments in Japan (Mochizuki et al. 2005).

Secondary poisoning from thalliumtreated grain used for ground squirrel (Spermophilus spp.) control was identified early in the last century (Linsdale 1931). Carnivorous mammals and predatory and scavenger birds (especially eagles) have been killed by Th sulfate $\left(\mathrm{Tl}_{2} \mathrm{SO}_{4}\right)$ and $\mathrm{Th}$ poisoning was reported in bald eagles in Wyoming in 1971, presumably from ingestion of $\mathrm{Tl}_{2} \mathrm{SO}_{4}$ laced baits (Cromartie et al. 1975). Implications of Th residues in nestling bald eagle blood found in this study are unknown. In the absence of mortality, morbidity, or reduced productivity attributed to $\mathrm{Th}$ in local populations residues may be inconsequential but should be monitored. 


\section{Organochlorines}

DDE (a metabolite of DDT) was the primary contaminant reducing reproductive success of bald eagles in North America with the majority of exposure from the avian portion of the diet (Wiemeyer 1991). Although DDE is less toxic to birds than most organochlorines, it can elicit abnormal behavior, eggshell thinning, and adult and embryonic mortality (Risebrough 1986). Low concentrations found in our study reflect the 1973 ban on DDT and subsequent decline in use, but continued presence (i.e., detection frequency) indicates long-term persistence of the chemical. A sequence of increasing residues is evident progressing downstream in the Missouri River watershed. A continual decline in residues can be expected barring unforeseen legalization and increasing use.

\section{$\downarrow$ ACKNOWLEDGEMENTS}

We wish to express our deepest appreciation to the following organizations and individuals for their collaboration in our research project: Dr. Alan Harmata, Montana State University; Grand Teton National Park (especially Andy Fisher, Renny Jackson, Ed Visnovske, Chris Harder, Scott Guenther, and Cindy O'Neill); Wyoming Game and Fish Department (especially Bob Oakleaf); and the University of Wyoming-National Park Service Research Station (especially Celeste Havener).

\section{$\downarrow$ Literature Cited}

ATSDR (Agency for Toxic Substances \& Disease Registry). 1992. Toxicological Profile for Antimony. U.S. Public Health Service, U.S. Department of Health and Human Services, Atlanta, GA.

ATSDR 1993. Toxicological Profile for Arsenic. Public Health Service, U.S. Department of Health and Human Services, Atlanta, GA.

ATSDR 1995. ToxFAQs ${ }^{\mathrm{TM}}$ for Thallium. Case number 7440-28-0. http://www.atsdr.cdc.gov/tfacts54.html
ATSDR 1997. Toxicological Profile for Nickel (Update). Public Health Service, U.S. Department of Health and Human Services, Atlanta, GA.

ATSDR 1998. Toxicological Profile for Chromium. U.S. Public Health Service, U.S. Department of Health and Human Services, Atlanta, GA. 1998.

Biswas, A., J. D.Blum and G. J. Keeler 2003. Forest fire effects on mercury and other trace metal concentrations in a Rocky Mountain forest ecosystem. EOS Transactions of American Geophysical Union 84 (46). Fall Meeting. Supplemental. Abstract \#B32C-05.

Boening, D.W. 2000. Ecological effects, transport, and fate of mercury: A general review. Chemosphere 40:13351351.

Bowerman, W. W. IV, E. D. Evans, J. P. Giesy, and S. Postupalsky. 1994. Using feathers to assess risk of mercury and selenium to bald eagle reproduction in the Great Lakes region. Archives of Environmental Contamination and Toxicology 27: 294-298.

Burgess, N.M, D. C. Evers, and J.D. Kaplan. 2005. Mercury and other contaminants incommon loons breeding in Atlantic Canada. Ecotoxicology 14:241-252.

Camardese, M. B., D. J. Hoffman, L. J. LeCaptain, and G. W. Pendleton. 1990. Effects ofarsenate on growth and physiology in mallard ducks. Environmental Toxicology and Chemistry 9:785-95.

Chen, C., H. Yu, J. Zhao, B. Li, L. Qu, S. Liu, P. Zhang, and Z. Chai . 2006. The roles of serum selenium and selenoproteins on mercury toxicity in environmental and occupational exposure. Environmental Health Perspectives 114:297-301.

Craighead, D. and B. Bedrosian, 2008. Blood levels of common ravens with access to big game offal. Journal of Wildlife Management. 
Cromartie, E., W.L. Reichel, L.N. Locke, A.A. Belisle, T.E. Kaiser, T.G. Lamont, B.M. Mulhern, R.M. Prouty, and D.M. Swineford. 1975. Residues of organochlorine pesticides and polychlorinated biphenyls and autopsy data for bald eagles, 1971-72. Pesticide Monitoring Journal 9:11-14.

Driscoll, C.T., C. Yan, C.L. Schofield, R. Munson, and J. Holsapple. 1994. The mercury cycle and fish in the Adirondack lakes. Environmental Science and Technology 28:136A143A.

Eisler, R. 1985a. Cadmium hazards to fish, wildlife, and invertebrates: A Synoptic Review. U.S. Department of Interior, Fish and Wildlife Service Biological Report 85 (1.2).

Eisler, R. 1985b. Selenium hazards to fish, wildlife, and invertebrates: A Synoptic Review. U.S. Department of Interior, Fish and Wildlife Service Biological Report 85 (1.5).

Fimreite, N. and L. Karstad. 1971. Effects of dietary methyl mercury on Red-Tailed Hawks. The Journal of Wildlife Management, 35(2):293-300, doi: $10.2307 / 3799603$

Friedli, H.R., L. F. Radke, and J. Y. Lu. 2001. Mercury in smoke from biomass fires. Geophysical Research Letters 28:32233226.

Friedli, H.R., L.F. Radke, J.Y. Lu, C.M. Banic, W.R. Leaitch, J.I. Mac Pherson. 2003. Mercury emissions from burning of biomass from temperate North American forests: laboratory and airborne measurements. Atmospheric Environment 37:253-267

Garcia, E. and R. Carignan. 2005. Mercury concentrations in fish from forest harvesting and fire-impacted Canadian boreal lakes compared using stable isotopes of nitrogen. Environmental Toxicology and Chemistry 24:685-693.

Harmata, A. R. 1996. Bald eagle management plan for Greater Yellowstone: 1995
Update. Greater Yellowstone Bald Eagle Working Group. Wyoming Game \& Fish Dept., Lander, Wyoming. 47 pp.

Harmata, A. R _ 2006. Monitoring mercury and other contaminants in bald eagles in southwestern Montana \& northwestern Wyoming. Interim Report - 30 November 2006

Harmata, A. R and G.J. Montopoli. 1998. Pied plumage in bald eagles. Journal of Field Ornithology 69:326-335.

Harmata, A. R., and B. Oakleaf. 1992. Bald Eagles of the Greater Yellowstone Ecosystem: An ecological study with emphasis on the Snake River, Wyoming. Wyoming Game \& Fish Dept., Lander. 368 pp.

Heinz, G.H. 1996. Mercury poisoning in wildlife. Pgs. 118-127 In Noninfectious diseases of wildlife. A. Fair-brother, L.N. Locke, and G.N. Hoff (eds.). Iowa State University Press, Ames, Iowa.

Heinz, G.H, D.J. Hoffman, and L.G. Gold. 1989. Impaired reproduction of mallards fed an organic form of selenium. The Journal of Wildlife Management 53: 418-428.

Henny, C.J., E.J. Kolbe, E.F. Hill, and L.J. Blus. 1987. Case histories of bald eagles and other raptors killed by organophosphorus insecticides topically applied to livestock. Journal Wildlife Diseases 23:292-295.

Hoffman, R.J., R.J. Hallock, T.G Rowe, M.S. Lico, H.L. Burge, and S.P. Thompson. 1990. Reconnaissance investigation of water quality, bottom sediment, and biota associated with irrigation drainage in and near Stillwater Wildlife Management Area, Churchill County, Nevada. Water Resource Invest. Rep. 89-4105. U.S. Geological Survey, Carson City, Nevada, 150 pp.

Hutton, M. 1981. Accumulation of heavy metals and selenium in three seabird species from the United Kingdom. Environmental Pollution. 26: 129-145. 
Kramer, J.L. and P.T. Redig. 1997. Sixteen years of lead poisoning in eagles, 198095: An epizootiologic view. Journal of Raptor Research 31:327-332.

Lemly, A.D. 1993. Guidelines for evaluating selenium data from aquatic monitoring and assessment studies. Ecotoxicology and Environmental Safety 26:181-204.

Linsdale, J.M. 1931. Facts concerning the use of $\mathrm{Th}$ in California to poison rodents: Its destructiveness to game birds, song birds and other valuable wild life. Condor 33:92-106.

Mochizuki, M., M. Mori, M. Akinaga, K.Yugami, C. Oya, R. Hondo, and F. Ueda. 2005. Th Contamination in Wild Ducks in Japan. Journal of Wildlife Diseases 41:664-668.

Nacci, D., M. Pelletier, J. Lake, R. Bennett, J. Nichols, R. Haebler. 2005. An approach to predict risks to wildlife populations from mercury and other stressors. Ecotoxicology 14: $283-293$.

NTP (National Toxicology Program). 1992. Toxicity Studies of Antimony Potassium Tartrate (CAS no.28300-74-5) in F344/N Rats and B6C3F1 Mice (Drinking Water and Intraperitoneal Injection Studies). Research Triangle Park, NC: U.S. Department of Health and Human Services, Public Health Service, National Institutes of Health.

Odsjo, T., A. Roos, and A.G. Johnels. 2004. The tail feathers of osprey nestlings (Pandion haliaetus L.) as indicators of change in mercury load in the environment of southern Sweden (19691998): a case study with a note on the simultaneous intake of selenium. Ambio 33:133-137.

Ohlendorf, H.M., R.L. Hothem, C.M. Bunck, T.W. Aldrich, and J.F. Moore. 1986. Relationships between selenium concentrations and avian reproduction. Transactions of the North American Wildlife and Natural Resources Conference 51:330-342.
Ohlendorf, H.M. 1989. Bioaccumulation and effects of selenium in wildlife. Pgs. 133-177 in Selenium in Agriculture and the Environment. Soil Science Society of America Special Publication no. 23.

Pattee, O.H., S.N. Wiemeyer, B.M. Mulhern, L. Sileo, and J.W. Carpenter. 1981. Experimental lead-shot poisoning in bald eagles. Journal of Wildlife Management 45:806-810.

Pattee, O.H. and S.K. Hennes. 1983. Bald eagles and waterfowl: The lead shot connection. Proceedings of the North American Wildlife Conference 48:230237.

Pelletier, E. 1985. Mercury-selenium interaction in aquatic organisms: a review. Mar. Environ. Res. 18: 111132.

Poley, W.E., A.L. Moxon, and K.W. Franke. 1937. Further studies of the effects of selenium poisoning on hatchability. Poultry Science 17:72-76.

Risebrough, R.W. 1986. Pesticides and bird populations. $\mathrm{P}$ in R.F. Johnston, ed. Current Ornithology, V3:397-427. Plenum Press, NY.

Rudd, J.W.M., M.A. Turner, B.E. Townsend, A. Swick, and A. Furitani. 1980. Dynamics of selenium in mercury-contaminated experimental ecosystems. Canadian Journal of Fishery \& Aquatic Science $37: 848$.

Sadiq, M. 1992. Toxic metal chemistry in marine environments. Marcel Dekker. New York.

Sindayigaya, E., R.V. Cauwnbergh, H. Robberecht, and H. Deelstra. 1994. Copper, zinc, manganese, iron, lead, cadmium, mercury, and arsenic in fish from Lake Tanganyika, Burundi. The Science of the Total Environment. 144:103-115.

Stanley, T.R., Jr., J.W. Spann, G.J. Smith, and R. Rosscoe. 1994. Main and interactive effects of arsenic and selenium on mallard reproduction and duckling 
growth and survival. Archives of Environmental Contamination and Toxicology. 26:444-451.

Turetsky, M.R., J.W. Harden, H. Friedli, M. Flannigan, N. Payne, J. Crock, L. Radke. 2006. Wildfires threaten mercury stocks in northern soils. Geophysical Research Letters 33:10.

Twining, B.S., M.R.Twiss, and N.S. Fisher. 2003. Oxidation of $\mathrm{Th}$ by Freshwater Plankton Communities. Environmental Science \& Technology 37:2720 - 2726.

U.S. Environmental Protection Agency. 1986. Health Assessment Document for Nickel. EPA/600/8-83/012F. National Center for Environmental Assessment, Office of Research and Development, Washington, DC.

U.S. Environmental Protection Agency. 1997. Mercury Study Report to Congress. USEPA, Washington, D.C. www.epa.gov/mercury/report.htm

U.S. Environmental Protection Agency (1) 1998. Toxicological Review of Hexavalent Chromium. National Center for Environmental Assessment, Office of Research and Development, Washington, DC.

U.S. Environmental Protection Agency (2) 1998. Toxicological Review of Trivalent Chromium. National Center for Environmental Assessment, Office of Research and Development, Washington, DC.
Weech, S.A., L. K. Wilson, K. M. Langelier, and J. E. Elliott. 2003. Mercury residues in livers of Bald Eagles (Haliaeetus leucocephalus) Found Dead or Dying in British Columbia, Canada (1987-1994). Archives of Environmental Contamination and Toxicology 45:562569

Wiemeyer, S.N. 1991. Effects of environmental contaminants on raptors in the Midwest. Pages 168-181 in Proceedings of the Midwest raptor management symposium and workshop. National Wildlife Federation, Washington, D.C.

Wiemeyer, S.N., C.M. Bunck, and C.J. Stafford. 1993. Environmental contaminants in bald eagle eggs-1980-84--and further interpretations of relationships to productivity and shell thickness. Archives of Environmental Contamination and Toxicology 24:213227.

White, D.H. and M.T. Finley. 1978. Uptake and retention of dietary cadmium in mallard ducks. Environmental Research 17:5359.

Whitworth, M.R., G.W. Pendleton, D.J. Hoffman, and M.B. Camardese. 1991. Effects of dietary boron and arsenic on the behavior of mallard ducks. Environmental Toxicology and Chemistry 10:911-916. 